Monitoramento de erosão laminar em diferentes usos da terra, Uberlândia - MG José Fernando Pinese Júnior, Lísia Moreira Cruz, Sílvio Carlos Rodrigues

\title{
MONITORAMENTO DE EROSÃO LAMINAR EM DIFERENTES USOS DA TERRA, UBERLÂNDIA - MG
}

\author{
The Monitoring of the Sheetflow Erosion in different Land Uses, Uberlândia - MG
}

\author{
José Fernando Pinese Júnior \\ Graduando em Geografia pela Universidade Federal de Uberlândia \\ zefernandopj@yahoo.com.br \\ Lísia Moreira Cruz \\ Graduanda em Geografia pela Universidade Federal de Uberlândia \\ lisia_mc@yahoo.com.br \\ Silvio Carlos Rodrigues \\ Professor Doutor do Instituto de Geografia da Universidade Federal de Uberlândia \\ silgel@ufu.br
}

Artigo recebido para publicação em 25/04/08 e aceito para publicação em 11/09/08

RESUMO: O processo erosivo quando agravado pela ação do homem traz problemas econômicos e ambientais, pois influenciam no nível de estabilidade do ambiente. Este trabalho foi desenvolvido na Fazenda Experimental do Glória/UFU com o objetivo de analisar e comparar a diferença do processo de erosão pluvial entre sete tipos de usos da terra. Para isso, foram coletados dados de umidade, escoamento superficial, transporte de sedimentos e ainda imagens da cobertura foliar de cada parcela para a fotocomparação. Para o experimento foram utilizadas parcelas experimentais ou parcelas de erosão, com inclinação de $5^{\circ}$ e uma calha de captação da água em sua parte inferior, permitindo assim que fosse coletado todo o material erodido. Como primeiro resultado foi visto que qualquer tipo de cobertura vegetal auxilia na contenção da erosão, com a interceptação das gotas da chuva e da radiação solar por parte das folhas. É visível também que com o escoamento superficial são transportadas partículas de solo e nutrientes e desta forma, os nutrientes presentes nas camadas superiores do solo são perdidos facilmente por erosão.

Palavras chave: Perda de solo; Parcelas experimentais; Foto-comparação; Geomorfologia.

ABSTRACT: When the soil erosion is accelerated by Humankind action, occur a lot of environmental and economic problems, just because the soil erosion has influence in environment stability. This research was developed at Glória Experimental Farm/UFU, and its objective was to make analyses and comparisons between pluvial soil erosion in seven different land uses. It was collected data about soil moisture, runoff, sediments transport and images from each land use in different times for making the photo-comparison to study the development of the vegetations. In this research were used erosion plots with slope of $5^{\circ}$ and a trough in its end part for collecting the water and sediments transported. As a first result, it was observed that any kind of vegetal cover helps in erosion decrease because of the interception of rain drops and the soil radiation by the vegetation leaves. It is possible to affirm that the runoff transports the sediments and the

Sociedade \& Natureza, Uberlândia, 20 (2): 157-175, DEZ. 2008 
Monitoramento de erosão laminar em diferentes usos da terra, Uberlândia - MG

José Fernando Pinese Júnior, Lísia Moreira Cruz, Sílvio Carlos Rodrigues

nutrients of soil, and so, the soil cover becomes inappropriate to the agriculture and for another uses.

Key words: Loss of soil; Experimental Plots; Photo-comparison; Geomorphology.

\section{INTRODUÇÃO}

O modelo de ocupação e a forma de uso da terra têm sido um processo desordenado em todo o país, com a retirada da vegetação para a prática de cultivos, não levando em conta áreas sensíveis à degradação ambiental. Não é diferente na região do Triângulo Mineiro em particular no município de Uberlândia, que também sentiu os reflexos desta ocupação sem planejamento.

Atrelados à modernização da agricultura, com técnicas inadequadas às condições tropicais, vieram os desmatamentos da vegetação nativa, tornando os solos mais susceptíveis à formação de processos erosivos. (SOUZA, 2005).

O processo de erosão consiste na retirada de material particulado, transporte e deposição de sedimentos. Guerra Silva \& Botelho (2005) descreve as etapas do processo erosivo, com a evolução da ação do splash, a formação de poças, que causarão posteriormente a formação de microrravinas e ravinas, uma vez que a água começa a escoar na superfície em lençol, passando para fluxos lineares.

Formadas as poças, a água começará a escoar na superfície em lençol, de maneira proporcional à inclinação do terreno, passando para fluxos lineares, que formaram as ravinas e microrravinas.

A presente pesquisa analisa o escoamento superficial, processo decorrente da erosão laminar ou erosão em lençol, descrita por Guerra, Silva \& Botelho (op. cit.):

A água que se acumula nas depressões do terreno começa a descer pela encosta quando o solo está saturado e as poças não conseguem mais conter essa água. A princípio, o afluxo é difuso, ou seja, um escoamento em lençol (sheetflow). (Guerra, Silva \& Botelho, 2005: 30).

Este processo é acelerado pelo homem com a intensificação das técnicas de manejo rural, com o intuito de aumentar a produtividade. Tal fato tem mudado severamente a paisagem, marcada por alguma degradação ambiental.

Partindo então para o entendimento do processo erosivo, é necessário saber que cada solo apresenta um certo índice de agregação entre suas partículas. A erosão acontece quando o potencial de transporte da água e/ou do vento ultrapassa o limite de agregação das partículas de solo, desprendendoas umas das outras e permitindo que possam então ser transportadas. Sendo assim, a erodibilidade dos solos depende, em grande parte, de suas propriedades, tais como teor de areia, silte e argila, teor de matéria orgânica, densidade aparente, porosidade e estabilidade de agregados, dentre outras. (GUERRA \& CUNHA, 1996).

O processo de erosão pluvial pode ser dividido em três etapas: desagregação, transporte e deposição (ELLISON, 1947; FOSTER \& MEYER, 1977 apud VOLK, 2006). A desagregação consiste na separação das partículas de solo, tanto pela ação de impacto das gotas, quanto pela ação cisalhante do escoamento originado da chuva. O transporte das partículas desagregadas também ocorre tanto pelo salpicamento gerado pelo impacto das gotas da chuva quanto pela enxurrada, que pode ser maior em terrenos inclinados. A deposição do material que foi desgastado e transportado representa a última etapa e "ocorre quando a carga de sedimentos na enxurrada é maior do que sua capacidade de transporte" (VOLK, 2006: 05).

O tipo de cobertura vegetal também tem grande relevância no entendimento do processo

Sociedade \& Natureza, Uberlândia, 20 (2): 157-175, DEZ. 2008 
Monitoramento de erosão laminar em diferentes usos da terra, Uberlândia - MG José Fernando Pinese Júnior, Lísia Moreira Cruz, Sílvio Carlos Rodrigues

erosivo, pois a infiltração da água das chuvas é favorecida pela cobertura foliar, amortecendo parte da água que atingiria o solo, através da interceptação pelas folhas, liberando lentamente a água para a superfície do solo e as raízes que abrem caminho para a água descendente no solo.

De acordo com Tricart (1977), a vegetação contribui fortemente para o equilíbrio do ecossistema de quatro maneiras diferentes: com a realização da fotossíntese; quando a radiação é absorvida pelas plantas; com a interceptação das precipitações e; com o efeito de sua rugosidade. Por isso será elaborado este estudo sobre os efeitos da vegetação nos processos erosivos, determinando diferentes tipos de culturas e suas particularidades em relação à perda de solo.

Segundo Galeti (1973: 67), “o controle à erosão deve ser o ponto de partida de qualquer empreendimento agrícola, deveria ser a primeira preocupação do agricultor". Isto se deve ao fato de a erosão causar também danos econômicos ao agricultor, pela perda de solo fértil, ou seja, áreas agricultáveis.

Portanto, diante de tais considerações, aliadas à relevância dos os processos erosivos atuais, têm-se a necessidade de avaliar os danos causados por diferentes tipos de ocupação da terra, assim como prever impactos ambientais com o intuito de apontar uma forma correta de manejo ou ainda de recuperação de áreas degradadas.

\section{OBJETIVOS}

Este estudo visa avaliar as perdas de solo por erosão pluvial em sete parcelas de erosão, as quais foram utilizadas com sete diferentes tratamentos. Os tratamentos são solo exposto (1), nas culturas de milho (2), sorgo (3) e soja (4), bem como as áreas de revegetação natural (5), brachiaria (6) e mata (7), elaborados segundo normas agronômicas que são aplicadas nestes usos da terra.

\section{FUNDAMENTAÇÃO TEÓRICO- METODOLÓGICA}

Os processos erosivos são capazes de modelar a paisagem, desgastando material de um local, transportando-o por meio da água ou do vento, e depositando-o quando não tem mais capacidade de transportá-lo. Porém o homem, em diferentes escalas, modifica o meio de tal forma a prejudicar a estabilidade destes acontecimentos.

Em toda e qualquer pesquisa sobre o processo erosivo torna-se importante analisar os fatores que conduzem à erosão pluvial, tais como a inclinação do terreno, o tipo de cobertura vegetal, a precipitação incidente, a morfologia, geologia e as características do solo no local.

Para definir a erosão pluvial ou pluvierosão temos que: é o trabalho realizado pela água das chuvas na superfície do relevo e é compreendida por três fases: 1-pluvierosão; 2-deplúvio; 3-aplúvio. Este trabalho de erosão das chuvas está diretamente ligado à intensidade da chuva, expressa pela quantidade de precipitação em um espaço de tempo. (GUERRA \& GUERRA, 2006).

As primeiras investigações científicas em erosão do solo foram feitas na Alemanha, entre os anos de 1877 e 1895 , em pequenas parcelas utilizadas para observações e medições de diversos efeitos relacionadas ao processo erosivo. Em 1923 ocorreu no Estado de Missouri, a primeira publicação de resultados de erosão pluvial do solo em parcelas experimentais de campo. (VOLK, 2006).

No Brasil, estudos em estações experimentais conduzidos por Baccaro (1993) e Guerra \& Cunha (1996) têm grande importância para o entendimento dos processos erosivos e compreendem a utilização de parcelas de erosão. Esta metodologia é bem descrita por Guerra \& Cunha (op. cit.), que orienta, nesta obra, como devem ser elaboradas e monitoradas as parcelas. No município de Uberlândia o Laboratório de Geomorfologia e Erosão dos Solos tem executado diversos estudos em estações 
Monitoramento de erosão laminar em diferentes usos da terra, Uberlândia - MG

José Fernando Pinese Júnior, Lísia Moreira Cruz, Sílvio Carlos Rodrigues

experimentais como os trabalhos de Bezerra et al (2006) e Pinese Júnior et al (2006).

Sendo assim, as parcelas de erosão são uma ferramenta importante no entendimento dos processos de erosão pluvial, atuando na representação de fatores mensuráveis, já que se tem uma área conhecida e que pode representar o tratamento e manejo direcionado de acordo com as necessidades da pesquisa.

A intensidade da chuva tem grande influência na erosão do solo, como afirma Volk (2006):

A capacidade da chuva de causar erosão do solo (erosividade da chuva) vai depender de várias das suas características, mas, principalmente, da intensidade, duração e probabilidade de ocorrência ou período de retorno da chuva. A intensidade da chuva resulta da razão entre quantidade e duração da mesma, enquanto esta última é a que vai determinar a quantidade total de chuva. (VOLK, 2006: 06).

A energia de impacto das gotas é responsável pela desagregação da maior parte do material que será transportado pelo escoamento superficial. Esse escoamento se inicia quando a intensidade da chuva é superior à taxa de infiltração instantânea do solo. $\mathrm{O}$ efeito do escoamento superficial na erosão pluvial depende da sua velocidade, que aumenta com o grau de declive e com a quantidade de escoamento. (MEYER \& MONKE, 1965 apud NUNES, 2006)

Em uma análise mais atenta, o impacto das gotas da chuva sobre uma fina camada de água provoca turbulência no escoamento superficial, aumentando a capacidade do fluxo em desagregar e transportar partículas de solo (NUNES, 2006).

Em geral, a inclinação do terreno influencia na intensidade do processo erosivo, pois quanto maior a inclinação da vertente, maior será a energia cinética da água que escoa superficialmente, e menor será a infiltração de água no solo, o que gera o escoamento superficial. Com o escoamento superficial são transportadas partículas de solo e nutrientes.
Desta forma, os nutrientes presentes nas camadas superiores do solo são perdidos facilmente por erosão. Os nitratos se ligam à água do escoamento superficial devido à sua alta solubilidade e os fosfatos se ligam as partículas finas do solo, sendo levados juntamente aos sólidos arrastados. Sendo assim, sabese que o material erodido é mais rico em nutrientes que o solo que sofreu erosão. (GUERRA, SILVA \& BOTELHO, 2005).

Guerra, Silva \& Botelho (2005) também propõe que a energia cinética da chuva deve ser utilizada para medir a erodibilidade da chuva:

[...] a energia cinética da chuva está relacionada à intensidade da chuva, porque é a energia total das gotas existentes em um evento de precipitação. (GUERRA, SILVA \& BOTELHO, 2005: 19)

É importante que o solo tenha agregados estáveis, mantendo assim sua estrutura e permitindo uma grande variedade de diâmetros dos seus poros. Desta forma, os agregados que apresentam poros com diâmetro maior do que $75 \mu \mathrm{m}$ determinam a taxa de infiltração de água, permitindo que ela infiltre por ação da força da gravidade. Ao mesmo tempo, os poros com diâmetro entre 0,1 e $15 \mu \mathrm{m}$ atuarão na retenção de água disponível para as plantas. (KARLEN \& STOTT apud VOLK, 2006).

A importância da preservação das florestas, principalmente em áreas de risco como vertentes muito inclinadas ou com precipitações elevadas, está fundamentada na proteção do solo contra a erosão, porque de acordo com Townsend et al (2006), o dossel das árvores absorve o impacto direto da chuva sobre a superfície, as raízes unem o solo e a queda contínua de folhas e estruturas das plantas, que caracterizam a serrapilheira, barram o escoamento superficial e o transporte de sedimentos, adicionando ainda matéria orgânica ao solo.

\section{ÁREA DE ESTUDO}

A área de estudo localiza-se na Fazenda Experimental do Glória/ UFU, situada no município 
de Uberlândia nas coordenadas geográficas de $18^{\circ} 56^{\prime} 56^{\prime \prime}$ de latitude Sul e $48^{\circ} 12^{\prime} 21^{\prime \prime}$ de longitude
Oeste de Greenwich, a uma altitude de 919 metros acima do nível do mar. (Figura 01).

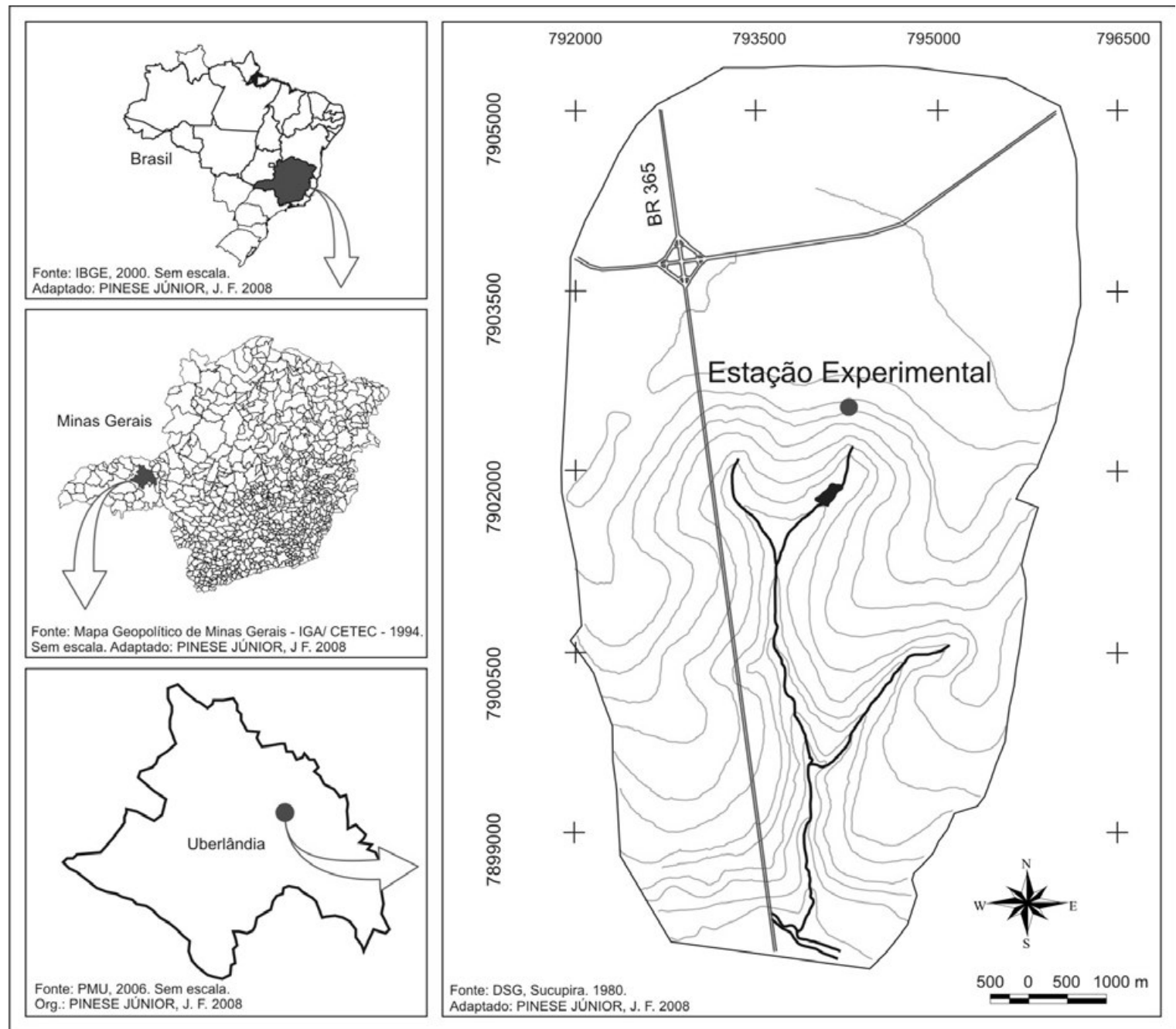

Figura 01: Mapa da área de contribuição da Bacia do Glória - Localização da estação experimental na Fazenda Experimental do Glória. Elaborado: PINESE JÚNIOR, 2008.

As condições climatológicas da região em que está instalada a estação são caracterizadas por um clima tropical de altitude com inverno seco e ameno, com baixa intensidade pluviométrica, e verão quente e chuvoso, classificado como Aw de acordo com a classificação de Köppen.

A precipitação média anual em Uberlândia está em torno de 1500 milímetros, sendo que os meses mais chuvosos são dezembro e janeiro, representando cerca de $40 \%$ da precipitação média anual, e os meses menos chuvosos são junho e julho. (Dados do Laboratório de Climatologia - UFU, 2008).

$\mathrm{Na}$ área de estudo, a formação geológica predominante é a Formação Marília, caracterizada como um pacote superior do Grupo Bauru e formada por arenitos com cimentação carbonática e por espessas camadas de arenitos imaturos e conglomerados. Situa-se no Domínio dos Planaltos e 
Chapadas da Bacia Sedimentar do Paraná, dentro da sub-unidade do Planalto Meridional da Bacia do Paraná, apresentando um relevo tabular a levemente ondulado. (CARRIJO \& BACCARO, 2000).

O solo presente na área de estudo é Latossolo Vermelho Distrófico e Nitossolo Vermelho Eutrófico (IBGE, 2001). A análise granulométrica de solos da área, realizada no Laboratório de Geomorfologia e Erosão dos Solos - LAGES/UFU, mostrou os níveis de areia, silte e argila para a identificação e caracterização do solo das parcelas, de acordo com a metodologia proposta pela EMBRAPA (1997). Esta análise definiu os teores de areia, silte e argila respectivamente com $20,9 \%, 3,9 \%$ e $75,2 \%$, caracterizando o solo da área como argila pesada, de acordo com o diagrama textural da EMBRAPA (op. cit.).

\section{METODOLOGIA}

\section{Definindo as parcelas}

O trabalho foi iniciado no dia 06 de dezembro de 2006, com a preparação adequada das parcelas de erosão e a coleta de dados, que se prolongou pelo período de um ano, de acordo com a metodologia proposta por Guerra \& Cunha (1996). As parcelas foram elaboradas com 1 metro de largura por 10 metros de comprimento e uma inclinação de $5^{\circ}$, delimitadas por folhas de zinco ou paredes de tijolos. O escoamento superficial é coletado por uma calha de captação posicionada na parte inferior de cada parcela. Este material coletado pela calha é conduzido por canos e armazenado por tambores com capacidade para até 120 litros (Figura 02).

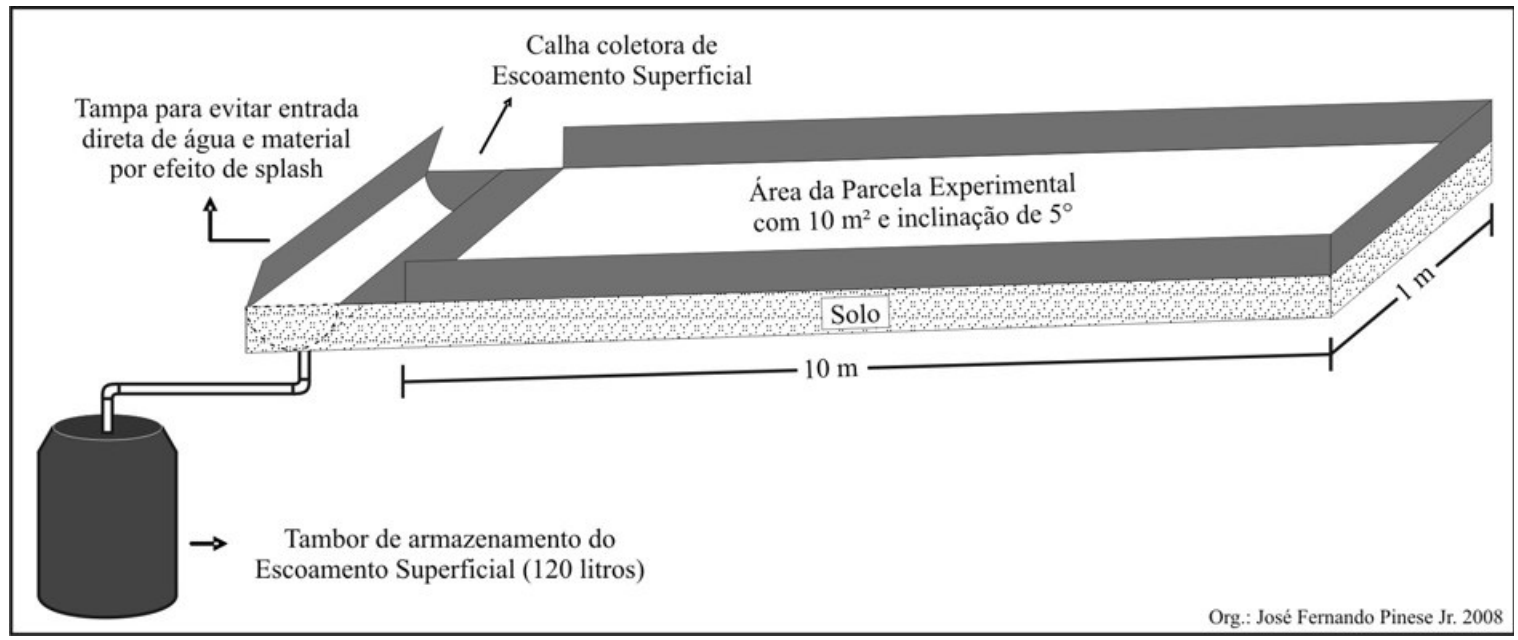

Figura 02: Esquema ilustrativo das parcelas experimentais. Org.: PINESE JÚNIOR, J. F.

As parcelas experimentais contêm sete tipos de usos da terra, simulando áreas de solo exposto (1), monocultura de milho (2), soja (3), sorgo (4), revegetação natural (5), brachiaria (6) e mata (7). As parcelas com solo exposto, milho, soja e sorgo foram preparadas e semeadas no dia 06 de dezembro de 2006. A parcela de revegetação natural foi preparada dois meses antes desta data, com a retirada de qualquer tipo de vegetal do local, para que germinasse apenas as sementes presentes no solo. Nesta parcela germinaram brachiaria e espécies arbustivas naturais do bioma cerrado.
As parcelas de brachiaria e mata foram preparadas em áreas que anteriormente já eram estes tipos de usos da terra.

A etapa de plantio seguiu as mesmas técnicas utilizadas no cerrado brasileiro, onde o solo é arado e assim descompactado, possibilitando então o plantio. Para a correção das deficiências em micronutrientes nos solos de cerrado a EMBRAPA (1997) recomenda a aplicação da fórmula 4-14-8 para a adubação NPK, atingindo a maior produtividade em plantio de milho 
e sorgo, na dose de $400 \mathrm{~kg}$ ha $\hat{I}^{1}$ e em plantio de soja, na dose de $350 \mathrm{~kg}$ ha $\hat{\mathrm{I}}^{1}$, na semeadura. Sendo assim, nas parcelas experimentais, configuradas com $10 \mathrm{~m}^{2}$, acrescentou-se $0,4 \mathrm{Kg}$ de adubo NPK nas culturas de milho e sorgo e $0,35 \mathrm{Kg}$ de adubo NPK na cultura de soja. A adubação com NPK na fórmula 4-14-8 proporciona uma melhor formação e desenvolvimento das raízes e demais estruturas das plantas. (FALLEIRO et al, 2003). As parcelas experimentais são cercadas e por isso não sofrem ação do trânsito de gado ou pessoas.

A calagem tem grande importância, principalmente nos solos do cerrado, na busca de neutralizar o $\mathrm{pH}$ do solo. Desta forma, o processo de calagem, que consiste na correção do pH do solo com aplicação de calcário para elevar os teores de cálcio (Ca) e magnésio $(\mathrm{Mg})$, deve ser realizado periodicamente, uma vez que grande parte do calcário é percolado para os perfis inferiores, prevalecendo o alumínio (Al) no perfil agricultável do solo. Este é um processo muito comum no cerrado brasileiro.

\section{Coletas de campo}

As coletas de campo para a pesquisa são realizadas semanalmente e consistem no monitoramento da umidade do solo, escoamento superficial e imagens da cobertura foliar para a fotocomparação, realizadas em cada uma das parcelas. Utilizaram-se ainda dados de uma estação climatológica instalada no local, que fornece valores de temperatura, umidade do ar, precipitação, insolação e velocidade e direção do vento. Esses dados podem complementar a comparação e o entendimento dos processos erosivos.

A captação das imagens foi feita através da câmera digital modelo Fuji Finepix S7000, abrangendo uma área de um metro quadrado, perpendicularmente ao solo, para registrar como as folha de cada tipo de cultura se comportam sob a ação das gotas de chuva.

O material armazenado pelos tambores é primeiramente homogeneizado e depois é coletado uma amostra de 2 litros para análise. Os valores de escoamento superficial são obtidos por meio da medição do material total presente nos tambores, feita com baldes graduados.

Os dados de umidade do solo são coletados pela sonda Theta Probe modelo ML2x, onde a umidade é medida no ponto em que são capturadas as imagens, a um metro acima da calha de captação de água. Este aparelho coleta os valores de umidade superficial, presente nos primeiros seis centímetros de solo.

\section{Análises laboratoriais}

As análises laboratoriais consistem no processamento das coletas de campo, já que em dias que houve escoamento superficial o material coletado deve ser filtrado para obtenção dos valores de transporte de sedimentos.

Do escoamento superficial ocorrido têm-se dois dados importantes para o estudo: a quantidade de água que não infiltrou no solo e a quantidade de sedimentos que este escoamento erodiu e transportou de cada parcela de $10 \mathrm{~m}^{2}$. A análise laboratorial consiste em filtrar os 2 litros de amostra coletados do fluxo superficial, medindo assim a quantidade de sedimentos transportados em cada parcela. Os filtros, feitos de papel filtro, são pesados depois de secos ao ar, antes e depois da filtragem, com uma balança de precisão da marca $A N D$, modelo $H R 200$ (Máximo: $210 \mathrm{~g} / \mathrm{d}=0,1 \mathrm{~g}$ ). Cada amostra das diferentes parcelas é passada por um respectivo papel filtro. Desprezando o peso do filtro obtém-se o valor do sedimento transportado nas diferentes parcelas da estação experimental.

$\mathrm{O}$ valor de sedimentos erodidos por metro quadrado $(M)$ em cada uma das parcelas é obtido pela seguinte fórmula:

$$
M=\frac{s \cdot f}{a \cdot c}
$$

onde: 
$M$ - Relação de sedimento transportado por metro quadrado $\left(\mathrm{g} / \mathrm{m}^{2}\right)$

$s$ - Total de sedimentos transportados por parcela $(\mathrm{g})$

$f$ - Total de escoamento superficial por parcela (L)

$a$ - Área da parcela experimental $\left(\mathrm{m}^{2}\right)$

$c$ - Quantidade de amostra coletada (L)

Sabe-se que a área da parcela experimental é de 10 metros quadrados e a amostra coletada sempre foi de dois litros quando o escoamento superficial excedia esta quantidade. Quando o escoamento não atingia dois litros coletava-se todo o material presente nos galões.

Para a realização da foto-comparação foi utilizado o software de tratamento de imagens ENVI ${ }^{\circledR}$ 4.0 (Environment for Visualizing Images - Research Systems, Inc.) que possibilita a quantificação da relação área protegida/área desprotegida, fator determinado pela vegetação. Feito isso, os dados percentuais nos permitem avaliar os efeitos da cobertura vegetal na contenção da erosão. O tratamento das imagens realizada no software ENVI ${ }^{\circledR}$ 4.0 permite separar as regiões de interesse em vegetação e solo desprotegido com cores distintas, tornando possível a foto-comparação. Sendo assim, quando comparadas ao transporte de sedimentos e ao escoamento superficial em cada parcela, as regiões de interesse revelam qual é a participação da cobertura vegetal na proteção da superfície do solo e seu papel na diminuição do material erodido.

A foto-comparação é feita comparando-se as imagens das diferentes parcelas e imagens de diferentes momentos do crescimento da vegetação. Desta maneira tornam-se mais claras as análises da evolução temporal e espacial da cobertura vegetal.

Neste trabalho optou-se por utilizar a metodologia da foto-comparação, com a comparação de imagens de cada parcela, pois permite diagnosticar as vantagens ou os problemas relacionados ao princípio da erosão que as diferentes coberturas vegetais trazem, já que as folhas das plantas são barreiras que amortecem as gotas de chuva. Porém, cada tipo de folha reage de uma maneira diferente a essas gotas de chuva, sendo esta diferença comparada por meio das imagens.

Os valores obtidos com o monitoramento no campo e análises laboratoriais passam por análises de regressão referentes ao coeficiente $r$ ou coeficiente de correlação linear segundo Pearson.

Foram feitas duas análises de correlação. A primeira foi feita entre os dados de escoamento superficial e precipitação e a segunda entre os dados de escoamento superficial e transporte de sedimentos.

Os modelos de regressão que geram o coeficiente de determinação $\left(\mathrm{R}^{2}\right)$ foram obtidos com o tratamento dos dados no Microsoft Office Excel 2007. Para esta análise de regressão elabora-se um gráfico de dispersão entre os dados que se quer analisar e adiciona-se a linha de regressão, com seu respectivo valor. $\mathrm{O}$ coeficiente de determinação é o quadrado do coeficiente de correlação de Pearson.

\section{RESULTADOS E DISCUSSÕES}

A presente pesquisa teve início com a preparação das parcelas experimentais e posteriormente as coletas, iniciadas no mês de janeiro de 2006 e finalizadas no mês de agosto de 2006. Tais coletas foram feitas semanalmente.

O clima no período do estudo, no ano de 2006, teve como meses mais chuvosos março e outubro, e os meses menos chuvosos junho e julho, como na maioria dos outros anos. (Gráfico 01). A precipitação total anual em 2006 foi de 1544 milímetros e a temperatura média foi de $22,5^{\circ} \mathrm{C}$, sendo que os meses mais quentes foram Janeiro $\left(24,5^{\circ} \mathrm{C}\right)$ e fevereiro $\left(24,2^{\circ} \mathrm{C}\right)$ e os meses mais frios junho $\left(19,8^{\circ} \mathrm{C}\right)$ e maio $\left(20^{\circ} \mathrm{C}\right)$. (Dados do Laboratório de Climatologia UFU, 2008). 


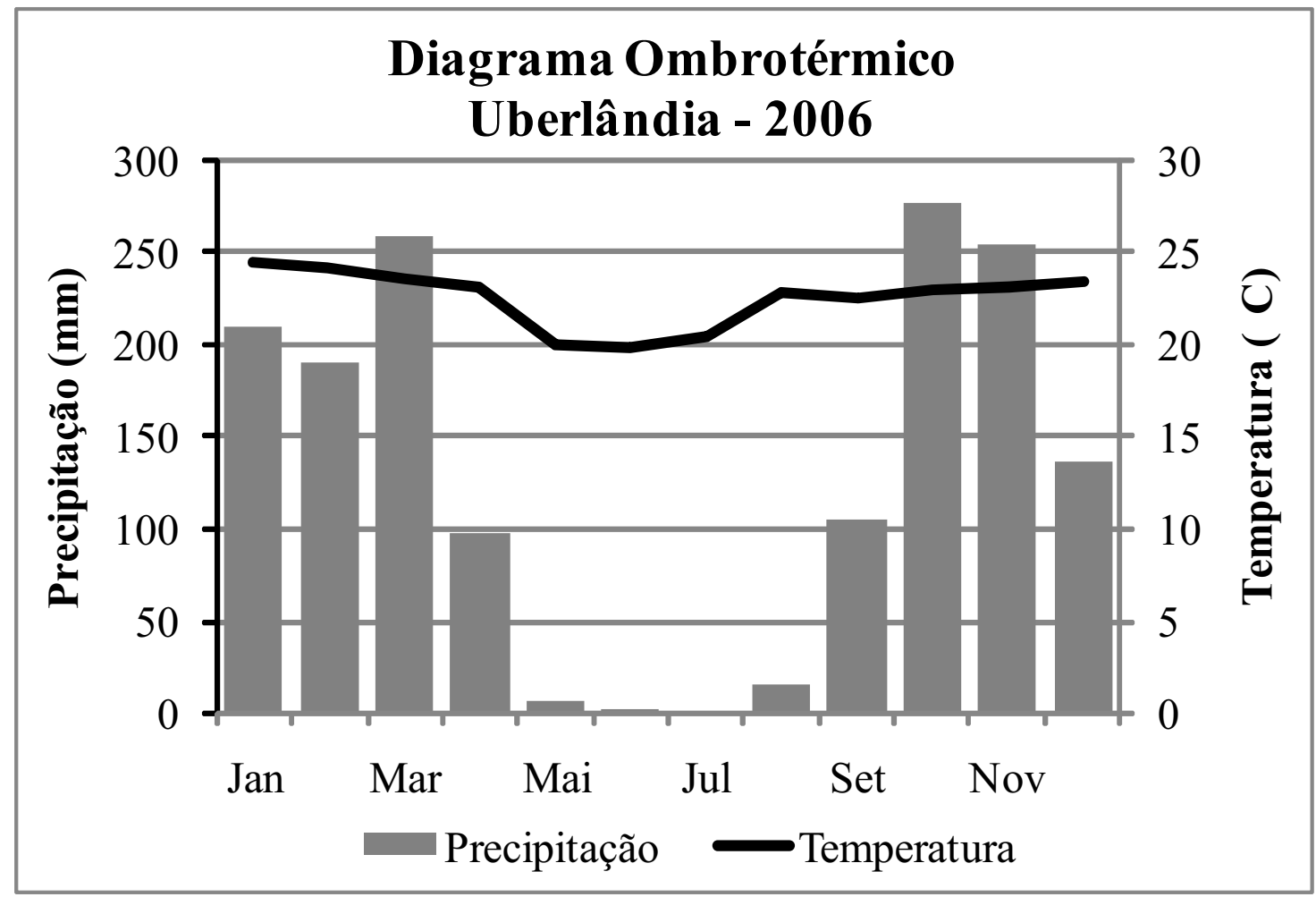

Gráfico 01: Diagrama Ombrotérmico de Uberlândia no ano de 2006. Elaborado: PINESE JÚNIOR, J. F.

A umidade do solo tem a capacidade de manter suas partículas unidas, e também confere à capacidade que a cobertura vegetal tem em mantê-la por um período de tempo maior do que quando a cobertura está ausente, pelo sombreamento e pelo fato de as estruturas das plantas amortecerem e, posteriormente, liberarem lentamente a água das chuvas.

O solo fica susceptível à erosão quando está encharcado, pois quando seus poros estão preenchidos por água começa então o escoamento superficial, já que não é mais possível a absorção da precipitação.

A área que se mostrou mais eficaz em manter a umidade do solo é a área de brachiaria, em que a estrutura de suas plantas consegue manter a umidade do solo por mais tempo após o período sem chuvas como é visto no período de 25 de abril a 19 de julho.
A parcela em área de mata também se mostra eficaz em manter a umidade em períodos de seca, pela ação protetora da serrapilheira e da copa das árvores.

A parcela com solo exposto teve valores ora muito elevados ora muito baixos, em relação às outras áreas, e isto se deve ao fato de este tipo de uso da terra não conseguir manter a umidade do solo. Quando há precipitação os valores de umidade são elevados, já que o solo fica saturado rapidamente, e quando não há precipitação ele perde a sua umidade também rapidamente, função esta que seria controlada pela presença de vegetação. A parcela com sorgo não apresentou bons resultados devido à estrutura de suas plantas, que possui folhas finas que não protegem o solo contra a radiação solar e conduzem as gotas da chuva à apenas um ponto no solo, assim como a estrutura da planta do milho. (Tabela 01) 
Monitoramento de erosão laminar em diferentes usos da terra, Uberlândia - MG

José Fernando Pinese Júnior, Lísia Moreira Cruz, Sílvio Carlos Rodrigues

Tabela 01: Umidade superficial do solo (\%) - 2006.

\begin{tabular}{|c|c|c|c|c|c|c|c|c|}
\hline \multirow{2}{*}{$\begin{array}{c}\text { Coleta } \\
\text { dasAmostras }\end{array}$} & \multicolumn{7}{|c|}{ Parcelas } & \multirow{2}{*}{$\begin{array}{l}\text { Precipitação } \\
(\mathrm{mm})\end{array}$} \\
\hline & 1 & 2 & 3 & 4 & 5 & 6 & 7 & \\
\hline 17/jan & 29,5 & 25,5 & 28,2 & 24,6 & 31,4 & 26,6 & 23,4 & 68,75 \\
\hline 24/jan & 25,0 & 21,0 & 31,0 & 29,6 & 29,5 & 29,8 & 23,1 & 38,75 \\
\hline 31/jan & 29,4 & 30,5 & 35,5 & 26,0 & 36,4 & 33,7 & 28,6 & 56,25 \\
\hline $7 /$ fev & 32,2 & 37,9 & 38,0 & 37,4 & 43,7 & 43,7 & 42,2 & 45,00 \\
\hline $14 / \mathrm{fev}$ & 32,2 & 32,7 & 36,7 & 33,8 & 39,6 & 34,9 & 20,4 & 28,75 \\
\hline $28 / \mathrm{fev}$ & 16,8 & 14,0 & 23,2 & 15,3 & 20,6 & 21,6 & 18,5 & 113,75 \\
\hline 7/mar & 8,2 & 12,7 & 15,9 & 12,3 & 15,4 & 14,1 & 12,1 & 0,00 \\
\hline $14 / \mathrm{mar}$ & 7,8 & 9,3 & 7,9 & 6,9 & 6,2 & 11,9 & 12,1 & 0,00 \\
\hline $21 / \mathrm{mar}$ & 28,1 & 28,8 & 31,9 & 20,8 & 28,2 & 28,5 & 25,3 & 60,00 \\
\hline $28 / \mathrm{mar}$ & 12,9 & 13,0 & 17,2 & 11,4 & 15,4 & 15,4 & 13,6 & 0,00 \\
\hline $11 / \mathrm{abr}$ & 14,7 & 16,9 & 18,7 & 14,3 & 17,4 & 17,2 & 15,0 & 17,50 \\
\hline 18/abr & 16,8 & 17,4 & 25,4 & 19,3 & 25,2 & 27,7 & 19,1 & 10,00 \\
\hline $25 / a b r$ & 9,1 & 10,0 & 14,8 & 9,0 & 10,9 & 15,3 & 13,7 & 0,00 \\
\hline 8/mai & 6,7 & 9,6 & 11,8 & 11,8 & 11,4 & 9,6 & 9,8 & 0,00 \\
\hline $15 / \mathrm{mai}$ & 9,1 & 10,1 & 10,3 & 8,1 & 9,9 & 11,6 & 13,3 & 0,00 \\
\hline $22 / \mathrm{mai}$ & 12,0 & 10,9 & 8,8 & 10,4 & 7,8 & 14,5 & 14,0 & 2,50 \\
\hline $28 /$ jun & 7,5 & 8,3 & 10,6 & 8,6 & 6,3 & 11,2 & 11,5 & 0,00 \\
\hline $5 /$ jul & 18,7 & 10,1 & 9,8 & 9,1 & 5,8 & 12,3 & 10,0 & 0,00 \\
\hline $12 / \mathrm{jul}$ & 4,2 & 6,9 & 5,9 & 6,6 & 8,7 & 10,6 & 8,2 & 0,00 \\
\hline 19/jul & 8,5 & 8,7 & 9,1 & 8,3 & 8,4 & 10,1 & 9,0 & 0,00 \\
\hline 26/jul & 11,3 & 9,1 & 20,6 & 9,7 & 21,7 & 19,3 & 15,4 & 16,25 \\
\hline 9/ago & 11,4 & 11,9 & 10,3 & 11,5 & 20,7 & 16,4 & 11,7 & 0,00 \\
\hline 16/ago & 9,9 & 13,7 & 11,4 & 10,0 & 13,3 & 11,7 & 9,0 & 0,00 \\
\hline Média & 15,8 & 16,0 & 18,8 & 15,4 & 18,9 & 19,5 & 16,5 & 19,89 \\
\hline
\end{tabular}

Legenda: 1 - Solo Exposto; 2 - Milho; 3 - Soja; 4 - Sorgo; 5 - Revegetação Natural; 6 - Brachiaria; 7 - Mata.

As áreas com soja e revegetação natural apresentam estrutura foliar mais eficazes na barreira dos raios solares, promovendo maior sombreamento do solo, e assim mantiveram sua umidade mais elevada.

As chuvas apresentam diferentes graus de erodibilidade, uma vez que quando é precipitado um grande volume em um curto período de tempo a água preenche os poros presentes no solo rapidamente, iniciando assim o fluxo superficial de água. Em períodos de chuvas torrenciais as parcelas que apresentaram maiores valores de escoamento superficial também foram as parcelas que apresentaram maiores valores de umidade.

A umidade do solo tem um comportamento complexo, agindo tanto a favor quanto contra a erosão pluvial do solo. Quando o solo está pouco úmido, está susceptível à erosão pluvial por não manter suas partículas agregadas, mas tem a capacidade de absorver mais água, evitando assim o escoamento superficial. Quando o solo está muito úmido suas partículas estão agregadas e são mais dificilmente 
separadas e transportadas pela ação do splash, porém ele está sujeito à saturação com o preenchimento de seus poros por água, que acarretará a formação de poças, e posteriormente o escoamento superficial quando o terreno for inclinado.

Com escoamento superficial são levadas partículas de solo, sejam elas dissolvidas no material que escoa ou transportadas por meio da energia cinética da água.

O escoamento superficial se mostrou inversamente proporcional à cobertura vegetal, indicando que esta é uma proteção eficaz para a contenção do fluxo superficial, por oferecer uma barreira física contra o aumento da energia cinética do escoamento. Quanto mais densa é a cobertura vegetal e a serrapilheira no solo, mais eficaz é a planta no controle do processo erosivo a estas condições. As plantas apresentam também caráter facilitador da infiltração e por isso aumentam a capacidade do solo em absorver água, dificultando assim a sua saturação por umidade.
A relação entre o escoamento superficial e os sedimentos transportados não foi muito forte nas parcelas em áreas de brachiaria e mata. A relação entre gramas de sedimentos transportados por litro de escoamento nestas parcelas foi menor do que a relação nas demais parcelas em todas as amostras coletadas.

Os valores de correlação entre o escoamento superficial e o transporte de sedimentos para a parcela com solo exposto é forte $(r=0,89)$, comprovando que a probabilidade de haver escoamento superficial quando ocorrer precipitação é elevada. (Tabela 02) As áreas com solo exposto não apresentam artifícios que aumentem a infiltração da água no solo e nem barreiras que impeçam o aumento da energia cinética do escoamento superficial, e que, sendo assim, atinge uma grande capacidade de transportar sedimentos.

A parcela em área de revegetação natural também apresentou correlação forte $(r=0,89)$ entre o escoamento superficial e a precipitação, uma vez que este tipo de vegetação é capaz de conter os sedimentos que foram erodidos, mas não é capaz de barrar o escoamento superficial.

Tabela 02: Valores do coeficiente de determinação $\left(\mathrm{R}^{2}\right)$ e da correlação de Pearson $(r)$, entre os valores de escoamento superficial e de precipitação.

\begin{tabular}{c|c|c}
\hline \multirow{2}{*}{ Parcelas } & \multicolumn{2}{|c}{ Correlação Linear } \\
\cline { 2 - 3 } & $\mathrm{R}^{2}$ & $r$ \\
\hline 1 & 0,809 & 0,89 \\
\hline 2 & 0,285 & 0,53 \\
\hline 3 & 0,292 & 0,54 \\
\hline 4 & 0,481 & 0,69 \\
\hline 5 & 0,806 & 0,89 \\
\hline 6 & 0,569 & 0,75 \\
\hline 7 & 0,116 & 0,34 \\
\hline
\end{tabular}

Legenda: 1 - Solo Exposto; 2 - Milho; 3 - Soja; 4 - Sorgo; 5 - Revegetação Natural; 6 - Brachiaria; 7 - Mata.

As correlações fracas entre os valores de escoamento superficial e precipitação indicam que mesmo com valores altos de precipitação não houve relação proporcional ao escoamento superficial, nestes usos da terra. Sendo assim as parcelas com correlação fraca entre escoamento superficial e precipitação são eficazes na contenção do fluxo descendente de água.

Os valores de escoamento superficial são 
maiores no período do plantio e vão gradativamente diminuindo com o crescimento da vegetação. $\mathrm{Na}$ primeira coleta, no dia 17 de janeiro, registrou-se valores altos de escoamento coletado pelos tambores das parcelas com solo exposto, milho, soja, sorgo e revegetação natural, com precipitação de 68,75 milímetros, e na nona coleta, no dia 21 de março, ou seja, depois de mais de 60 dias e com a vegetação já crescida, os valores foram significativamente mais baixos nestas parcelas, mesmo com quantidade de precipitação de 60,00 milímetros. Os valores de escoamento superficial foram $25 \%$ menor na parcela de solo exposto, $92,5 \%$ menor na parcela de milho, $88,3 \%$ menor na parcela de soja, $88,5 \%$ na parcela de sorgo e $78,78 \%$ menor na parcela de revegetação natural. Tal fato comprova a eficiência da vegetação em proteger a área contra o escoamento superficial, uma vez que a precipitação foi apenas $12,72 \%$ menor, entre a primeira e a nona coleta, e o escoamento superficial decresceu mais de $75 \%$ nas parcelas com vegetação e apenas $25 \%$ na parcela com solo exposto. (Tabela 03).

Tabela 03: Escoamento Superficial $\left(\mathrm{L} / \mathrm{m}^{2}\right)-2006$.

\begin{tabular}{|c|c|c|c|c|c|c|c|c|}
\hline \multirow{2}{*}{$\begin{array}{c}\text { Coleta } \\
\text { dasAmostras }\end{array}$} & \multicolumn{7}{|c|}{ Parcelas } & \multirow{2}{*}{$\begin{array}{c}\text { Precipitação } \\
(\mathrm{mm})\end{array}$} \\
\hline & 1 & 2 & 3 & 4 & 5 & 6 & 7 & \\
\hline 17/jan & 12,0 & 12,0 & 12,0 & 6,1 & 6,6 & 0,7 & 0,0 & 68,75 \\
\hline 24/jan & 10,4 & 0,9 & 1,0 & 1,0 & 0,7 & 0,0 & 0,0 & 38,75 \\
\hline 31/jan & 12,0 & 0,9 & 1,3 & 1,5 & 3,0 & 0,3 & 0,0 & 56,25 \\
\hline $7 /$ fev & 3,0 & 0,6 & 1,3 & 1,2 & 1,8 & 0,3 & 0,4 & 45,00 \\
\hline $14 /$ fev & 0,7 & 0,4 & 0,5 & 0,6 & 0,7 & 0,1 & 0,0 & 28,75 \\
\hline $28 / \mathrm{fev}$ & 12,0 & 2,2 & 1,7 & 2,0 & 12,0 & 6,0 & 0,1 & 113,75 \\
\hline 7/mar & 0,0 & 0,0 & 0,0 & 0,0 & 0,0 & 0,0 & 0,0 & 0,00 \\
\hline $14 / \mathrm{mar}$ & 0,0 & 0,0 & 0,0 & 0,0 & 0,0 & 0,0 & 0,0 & 0,00 \\
\hline 21/mar & 9,0 & 0,9 & 1,4 & 0,7 & 1,4 & 0,3 & 0,0 & 60,00 \\
\hline $28 / \mathrm{mar}$ & 0,0 & 0,0 & 0,0 & 0,0 & 0,0 & 0,0 & 0,0 & 0,00 \\
\hline 11/abr & 2,7 & 0,6 & 0,4 & 0,3 & 0,5 & 0,0 & 0,0 & 17,50 \\
\hline 18/abr & 0,1 & 0,1 & 0,1 & 0,1 & 0,2 & 0,0 & 0,0 & 10,00 \\
\hline 25/abr & 0,0 & 0,0 & 0,0 & 0,0 & 0,0 & 0,0 & 0,0 & 0,00 \\
\hline 8/mai & 0,0 & 0,0 & 0,0 & 0,0 & 0,0 & 0,0 & 0,0 & 0,00 \\
\hline $15 /$ mai & 0,0 & 0,0 & 0,0 & 0,0 & 0,0 & 0,0 & 0,0 & 0,00 \\
\hline 22/mai & 0,0 & 0,0 & 0,0 & 0,0 & 0,0 & 0,0 & 0,0 & 2,50 \\
\hline 28/jun & 0,0 & 0,0 & 0,0 & 0,0 & 0,0 & 0,0 & 0,0 & 0,00 \\
\hline 5/jul & 0,0 & 0,0 & 0,0 & 0,0 & 0,0 & 0,0 & 0,0 & 0,00 \\
\hline 12/jul & 0,0 & 0,0 & 0,0 & 0,0 & 0,0 & 0,0 & 0,0 & 0,00 \\
\hline 19/jul & 0,0 & 0,0 & 0,0 & 0,0 & 0,0 & 0,0 & 0,0 & 0,00 \\
\hline 26/jul & 3,8 & 0,9 & 0,7 & 1,1 & 1,0 & 0,0 & 0,0 & 16,25 \\
\hline 9/ago & 0,0 & 0,0 & 0,0 & 0,0 & 0,0 & 0,0 & 0,0 & 0,00 \\
\hline 16/ago & 0,0 & 0,0 & 0,0 & 0,0 & 0,0 & 0,0 & 0,0 & 0,00 \\
\hline Total & 65,7 & 19,5 & 20,4 & 14,5 & 27,9 & 7,9 & 0,5 & 457,5 \\
\hline
\end{tabular}

Legenda: 1 - Solo Exposto; 2 - Milho; 3 - Soja; 4 - Sorgo; 5 - Revegetação Natural; 6 - Brachiaria; 7 - Mata. 
De acordo com observações feitas no campo é possível registrar algumas conclusões sobre os sedimentos que são transportados. O material transportado em parcelas com cobertura foliar densa representa um material fino, composto por silte, argila e areia fina, apesar de conter a mesma quantidade ou até mesmo mais água escoada, quando comparada às parcelas com menor cobertura foliar, em um mesmo período de coleta.
A maior parte dos sedimentos que foram transportados é proveniente da parcela com solo exposto. Esta parcela apresentou valores elevados em relação às outras parcelas em todas as coletas. No início das coletas houve um maior transporte de sedimentos quando comparados aos valores a partir da terceira semana. Estes valores no início das coletas são maiores devido ao plantio realizado nas parcelas, onde o solo é descompactado por meio da aração, e assim suas partículas estão susceptíveis à erosão (Tabela 04).

Tabela 04: Transporte de Sedimentos $\left(\mathrm{g} / \mathrm{m}^{2}\right)-2006$.

\begin{tabular}{|c|c|c|c|c|c|c|c|c|}
\hline \multirow{2}{*}{$\begin{array}{c}\text { Coleta } \\
\text { dasAmostras }\end{array}$} & \multicolumn{7}{|c|}{ Parcelas } & \multirow{2}{*}{$\begin{array}{l}\text { Precipitação } \\
\text { (mm) }\end{array}$} \\
\hline & 1 & 2 & 3 & 4 & 5 & 6 & 7 & \\
\hline 17/jan & 487,68 & 139,62 & 14,16 & 2,50 & 1,25 & 0,16 & 0,00 & 68,75 \\
\hline $24 /$ jan & 77,68 & 1,66 & 0,52 & 0,96 & 0,09 & 0,00 & 0,00 & 38,75 \\
\hline $31 /$ jan & 93,41 & 2,15 & 0,87 & 2,67 & 0,51 & 0,05 & 0,00 & 56,25 \\
\hline $7 /$ fev & 1,21 & 0,06 & 0,11 & 0,23 & 0,07 & 0,02 & 0,04 & 45,00 \\
\hline $14 /$ fev & 1,63 & 0,04 & 0,25 & 0,02 & 0,03 & 0,13 & 0,00 & 28,75 \\
\hline $28 / \mathrm{fev}$ & 53,10 & 0,19 & 0,29 & 0,16 & 0,42 & 0,36 & 0,04 & 113,75 \\
\hline $7 / \mathrm{mar}$ & 0,00 & 0,00 & 0,00 & 0,00 & 0,00 & 0,00 & 0,00 & 0,00 \\
\hline $14 / \mathrm{mar}$ & 0,00 & 0,00 & 0,00 & 0,00 & 0,00 & 0,00 & 0,00 & 0,00 \\
\hline $21 / \mathrm{mar}$ & 33,12 & 0,29 & 0,07 & 0,01 & 0,02 & 0,03 & 0,00 & 60,00 \\
\hline $28 / \mathrm{mar}$ & 0,00 & 0,00 & 0,00 & 0,00 & 0,00 & 0,00 & 0,00 & 0,00 \\
\hline 11/abr & 9,84 & 0,12 & 0,14 & 0,05 & 0,02 & 0,03 & 0,00 & 17,50 \\
\hline $18 / \mathrm{abr}$ & 3,48 & 0,01 & 0,04 & 0,00 & 0,00 & 0,02 & 0,00 & 10,00 \\
\hline $25 / a b r$ & 0,00 & 0,00 & 0,00 & 0,00 & 0,00 & 0,00 & 0,00 & 0,00 \\
\hline $8 / \mathrm{mai}$ & 0,00 & 0,00 & 0,00 & 0,00 & 0,00 & 0,00 & 0,00 & 0,00 \\
\hline $15 / \mathrm{mai}$ & 0,00 & 0,00 & 0,00 & 0,00 & 0,00 & 0,00 & 0,00 & 0,00 \\
\hline $22 /$ mai & 0,00 & 0,00 & 0,00 & 0,00 & 0,00 & 0,00 & 0,00 & 2,50 \\
\hline 28/jun & 0,00 & 0,00 & 0,00 & 0,00 & 0,00 & 0,00 & 0,00 & 0,00 \\
\hline $5 /$ jul & 0,00 & 0,00 & 0,00 & 0,00 & 0,00 & 0,00 & 0,00 & 0,00 \\
\hline 12/jul & 0,00 & 0,00 & 0,00 & 0,00 & 0,00 & 0,00 & 0,00 & 0,00 \\
\hline 19/jul & 0,00 & 0,00 & 0,00 & 0,00 & 0,00 & 0,00 & 0,00 & 0,00 \\
\hline 26/jul & 0,89 & 0,13 & 0,34 & 0,19 & 0,00 & 0,00 & 0,00 & 16,25 \\
\hline 9/ago & 0,00 & 0,00 & 0,00 & 0,00 & 0,00 & 0,00 & 0,00 & 0,00 \\
\hline 16/ago & 0,00 & 0,00 & 0,00 & 0,00 & 0,00 & 0,00 & 0,00 & 0,00 \\
\hline Total & 762,07 & 144,30 & 16,83 & 6,82 & 2,42 & 0,83 & 0,08 & 457,5 \\
\hline
\end{tabular}

Legenda: 1 - Solo Exposto; 2 - Milho; 3 - Soja; 4 - Sorgo; 5 - Revegetação Natural; 6 - Brachiaria; 7 - Mata.

$\mathrm{Na}$ parcela em área de revegetação natural ocorreu grande escoamento superficial e baixo 
transporte de sedimentos, quando comparado às demais parcelas. Isto se deve ao fato de esta área se mostrar eficaz na contenção do transporte de sedimentos e não na contenção do escoamento superficial. Suas estruturas são eficazes na barragem de sedimentos presentes no escoamento superficial, mas não auxiliam a penetração da água no solo.

Analisando-se os dados somados de escoamento superficial e transporte de sedimentos de todo o período de monitoramento, obtém-se uma visão do quanto de material foi erodido (Gráfico 02).

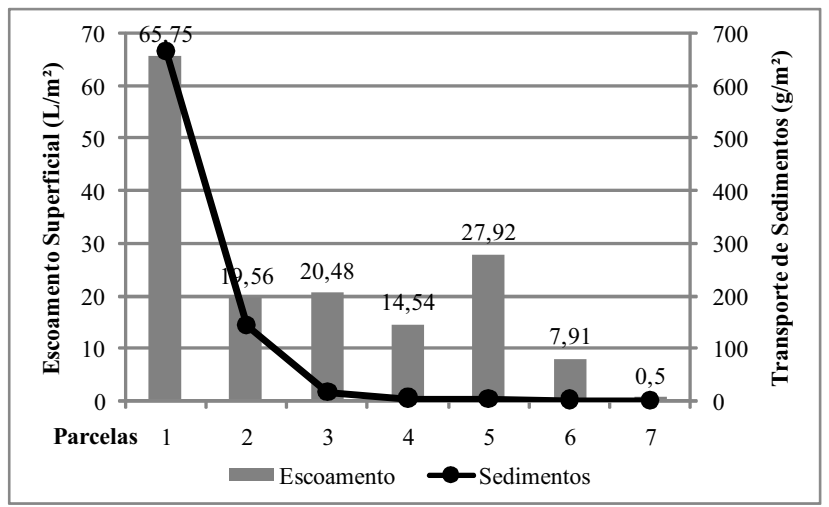

Gráfico 02: Total de escoamento superficial e sedimentos transportados durante o monitoramento das parcelas experimentais. Elaborado: PINESE JÚNIOR, J. F. Legenda: 1 - Solo Exposto; 2 - Milho; 3 - Soja; 4 - Sorgo; 5 - Revegetação Natural; 6 - Brachiaria; 7 - Mata.

A parcela com solo exposto perde cerca de quatro vezes mais material do que qualquer outro uso da terra. Ao final do experimento, ou seja, depois de sete meses de ação dos processos erosivos, esta parcela perdeu $665,17 \mathrm{~g} / \mathrm{m}^{2}$, o que representa 66,517 $\mathrm{Kg} / \mathrm{ha}$ de solo erodido, enquanto a parcela com milho perdeu $14,214 \mathrm{Kg} / \mathrm{ha}$ de solo erodido. A área da mata foi a mais eficaz na proteção contra a erosão laminar do solo, perdendo $0,008 \mathrm{Kg} /$ ha de solo, e da área com brachiaria foi erodido $0,076 \mathrm{Kg} / \mathrm{ha}$. Comparativamente, estudos realizados por Guerra, Silva \& Botelho
(2005) contabilizam que a perda de solo na mata seja de $4 \mathrm{~kg} / \mathrm{ha}$. ao ano e brachiaria $700 \mathrm{~kg} / \mathrm{ha}$. ao ano.

Analisando os dados da tabela 05 ressalta-se que a parcela com solo exposto não apresenta forte correlação entre escoamento superficial e transporte de sedimentos por apresentar sempre um valor elevado de sedimentos transportados, independente da quantidade de escoamento superficial. Isto representa a facilidade destas áreas em perderem solo, mesmo em chuvas fracas.

Tabela 05: Valores do coeficiente de determinação $\left(\mathrm{R}^{2}\right)$ e da correlação de Pearson $(r)$, entre os valores de escoamento superficial e transporte de sedimentos.

\begin{tabular}{c|c|c}
\hline Parcelas & \multicolumn{2}{|c}{ Correlação Linear } \\
\hline 1 & $\mathrm{R}^{2}$ & $r$ \\
\hline 2 & 0,402 & 0,63 \\
\hline 3 & 0,956 & 0,97 \\
\hline 4 & 0,966 & 0,98 \\
\hline 5 & 0,583 & 0,76 \\
\hline 6 & 0,491 & 0,70 \\
\hline 7 & 0,813 & 0,90 \\
\hline
\end{tabular}

Legenda: 1 - Solo Exposto; 2 - Milho; 3 - Soja; 4 - Sorgo; 5 - Revegetação Natural; 6 - Brachiaria; 7 - Mata.

Sociedade \& Natureza, Uberlândia, 20 (2): 157-175, DEZ. 2008 
As demais parcelas com valores de correlação menores, representadas pelas parcelas com sorgo, revegetação natural e mata, são as areas em que as proporções de transporte de sedimentos não acompanharam o escoamento destas parcelas, ou seja, os sedimentos não foram transportados pelo escoamento superficial, como visto em outras parcelas. As parcelas com milho, soja e brachiaria possuem forte correlação entre os valores de escoamento superficial e transporte de sedimentos, o que indica que estes tipos de vegetação agem proporcionalmente iguais na contenção do escoamento superficial e do transporte de sedimentos.

A erosão que ocorreu nas parcelas foi a do tipo laminar, em que a desagregação e deslocamento do material se processam superficialmente, sem a ocorrência de sulcos. A erosão desgasta por igual, retirando uma lâmina da superfície, da mesma forma que descrito nos estudos de Galeti (1973).

Não houve a formação de sulcos de erosão devido ao comprimento da parcela e a baixa inclinação do local, que não permitem que o escoamento superficial atinja uma maior velocidade.

Na parte superior da parcela com solo exposto está ocorrendo o encrostamento do solo. Este processo está relacionado à constante exposição do solo às chuvas e também à sua intensidade.

A cobertura vegetal tem o papel inicial de barrar as gotas da chuva, anulando o papel do splash, que poderia desagregar as partículas e provocar a selagem superficial do solo. Posteriormente, as raízes e o tronco da planta oferecem resistência aos materiais transportados superficialmente pela água.

Com o tratamento das imagens originais (figura 04), por meio da foto-comparação, expõem a relação existente entre a cobertura vegetal e a erosão dos solos. Existe uma forte relação entre a cobertura vegetal e o transporte de sedimentos, de forma inversamente proporcional.

Nas imagens do período do plantio, em que foi feito o tratamento (Figura 05), os tons escuros representam as áreas da imagem com solo exposto e os tons claros representam as áreas com folhas ou com alguma cobertura biológica no solo, como serrapilheira ou raízes. A parcela com revegetação natural, que possui maior porcentagem de cobertura foliar revelada pelo tratamento das imagens no software, apresentou baixos valores de partículas transportadas na respectiva data.
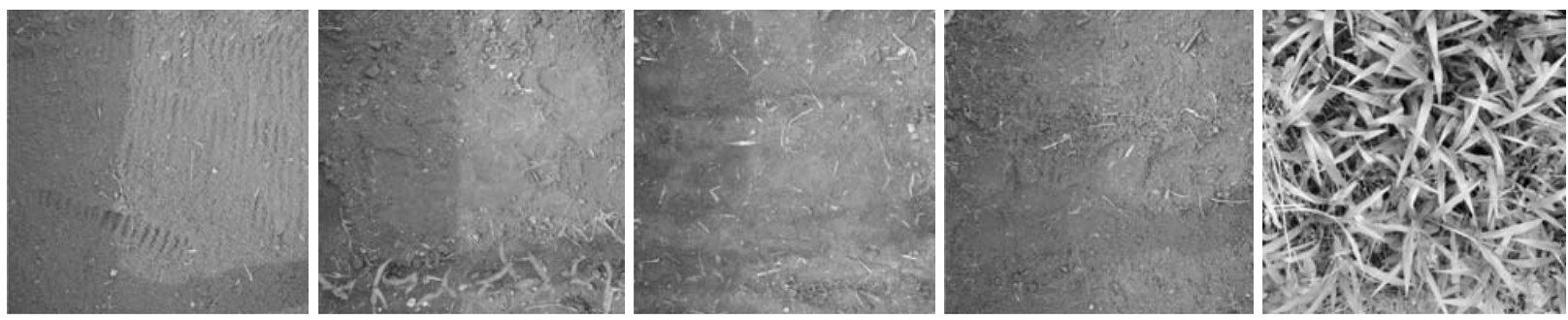

Figura 04: Imagens originais das parcelas experimentais após o plantio. (06/12/06)
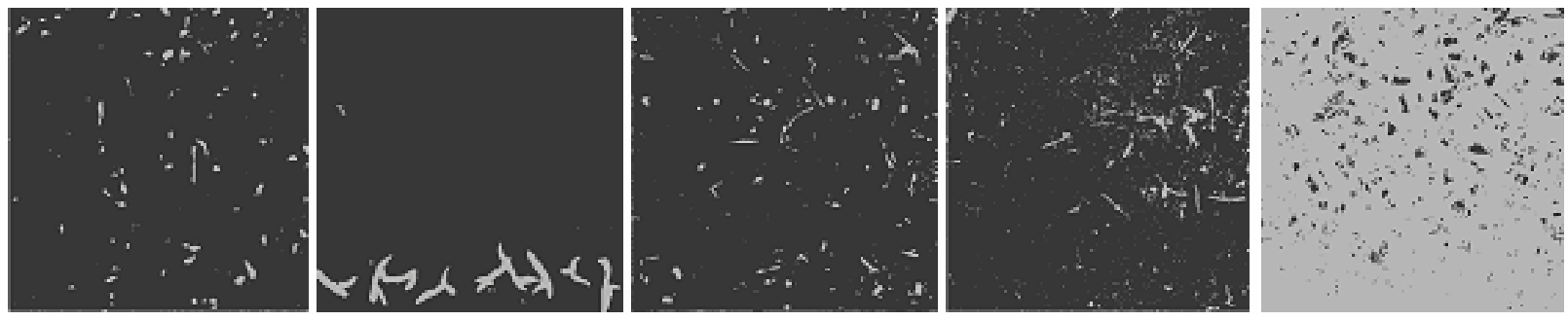

Figura 05: Imagens das parcelas experimentais após o plantio com divisão em duas regiões de interesse. (06/12/06) 
Com as imagens capturadas no período anterior à colheita (Figura 06), foi feita a fotocomparação, pois este período representa o ponto máximo de cobertura da vegetação. Esta comparação entre o crescimento da vegetação avaliou a importância da cobertura vegetal na proteção contra a erosão laminar, já que as parcelas de milho, soja, sorgo e revegetação natural, que apresentam maior cobertura do solo, são as que tiveram valores mais baixos quanto ao transporte de sedimentos. (Figura 07).
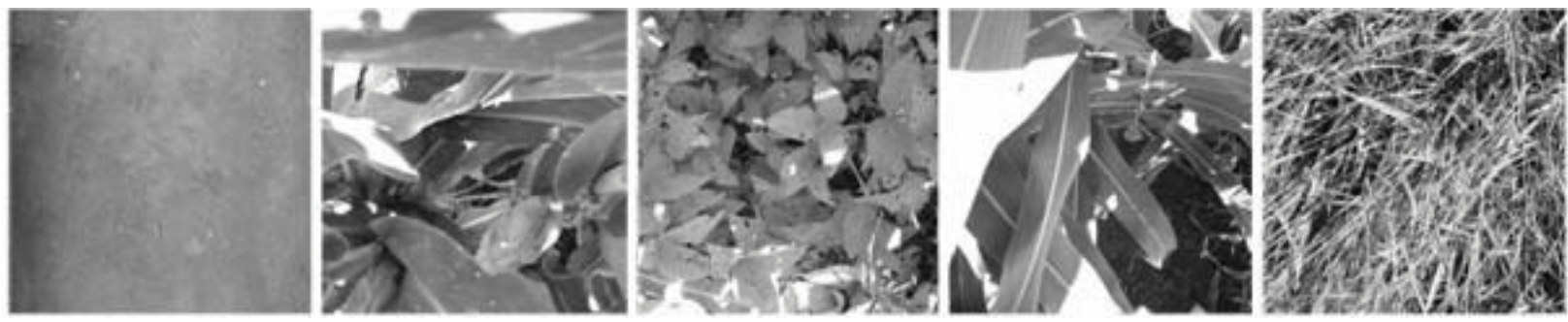

Figura 06: Imagens originais das parcelas experimentais antes da colheita. (14/03/07)
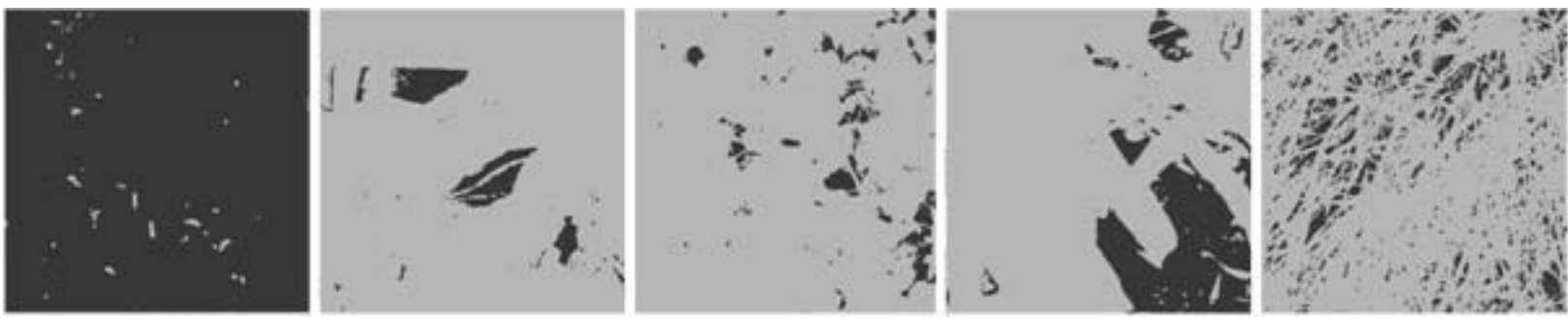

Figura 07: Imagens das parcelas experimentais antes da colheita com divisão em duas regiões de interesse. (14/03/07)

A diminuição do transporte de sedimentos pode ser medida em relação à evolução da cobertura vegetal (Tabela 06). No período final da captura das imagens, em um momento anterior à colheita, nota- se que o valor de sedimentos transportados da parcela com solo exposto permaneceu maior quando comparado às demais parcelas com cobertura vegetal, uma vez que seu solo está compactado e sem proteção.

Tabela 06: Valores porcentuais de cobertura vegetal e de solo exposto em diferentes momentos evolutivos da vegetação, extraídos a partir do software $\mathrm{ENVI}^{\circledR}$.

\begin{tabular}{c|c|c|c|c}
\hline \multirow{2}{*}{ Parcelas } & \multicolumn{2}{|c|}{ Após o Plantio - 6/12/2006 } & \multicolumn{2}{c}{ Antes da Colheita - 14/3/2007 } \\
\cline { 2 - 5 } & Solo Exposto (\%) & Cobertura Vegetal (\%) & Solo Exposto (\%) & Cobertura Vegetal (\%) \\
\hline 1 & 97,099 & 2,901 & 98,513 & 1,487 \\
\hline 2 & 96,393 & 3,607 & 5,639 & 94,361 \\
\hline 3 & 96,768 & 3,232 & 5,693 & 94,307 \\
\hline 4 & 94,654 & 5,346 & 18,463 & 81,537 \\
\hline 5 & 6,208 & 93,792 & 14,141 & 85,859 \\
\hline
\end{tabular}

Legenda: 1 - Solo Exposto; 2 - Milho; 3 - Soja; 4 - Sorgo; 5 - Revegetação Natural.

As parcelas de milho, soja, sorgo, e revegetação natural, que possuem mais de $81 \%$ do solo coberto pelas plantas, apresentaram baixos valores de transporte de sedimentos no período 
anterior à colheita, com respectivamente 0,$29 ; 0,07$; 0,01 ; e 0,02 gramas de sedimentos transportados por metro quadrado, enquanto a parcela com solo exposto, que apresenta 1,487\% do solo coberto por vegetação, teve 33,12 gramas de sedimentos transportados por metro quadrado. (Gráfico 03)

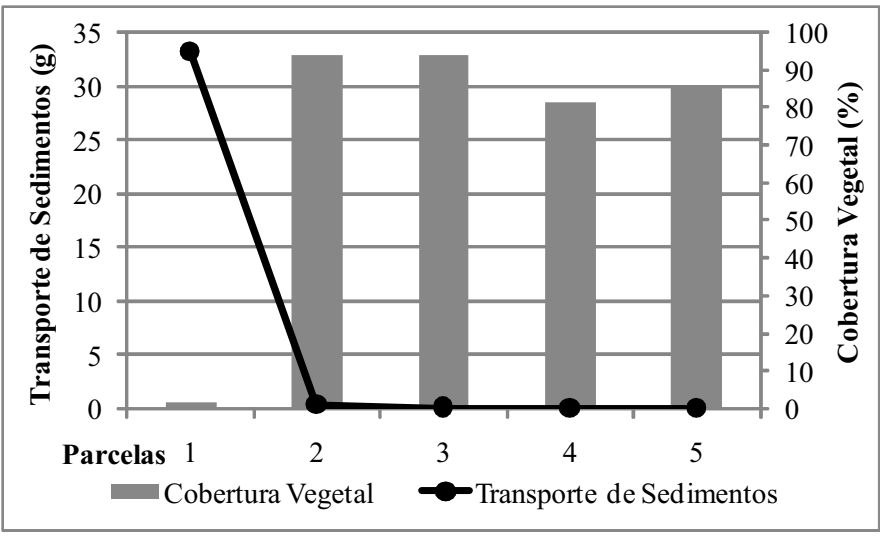

Gráfico 03: Transporte de sedimentos em relação à cobertura vegetal na semana antes da colheita - 14/03/07. Legenda: 1 - Solo Exposto; 2 - Milho; 3 - Soja; 4 - Sorgo; 5 - Revegetação Natural.

\section{CONSIDERAÇÕES FINAIS}

Os problemas de erosão que ocorrem na área rural do município de Uberlândia, no Domínio de Cerrado, estão ligados à atividade antrópica, com o uso inadequado da terra. É preciso atenção especial às áreas com solo exposto ou mesmo entre um plantio e outro, em que o solo fica sem vegetação e neste curto período de tempo o processo erosivo é intenso, pois ocorre a perda de solo e principalmente de nutrientes. Atenção especial deve ser dada também, às áreas inclinadas onde a erosão pode ser acelerada.

A mecanização da agricultura também contribui para a formação de processos erosivos, pois o uso de maquinário em grande escala e de forma inadequada torna o solo muito compacto. A compactação do solo aumenta o escoamento superficial e, dependendo da declividade do terreno e do uso da terra, podem ocorrer sulcos e ravinas, levando em alguns casos à formação de voçorocas.

Os resultados sobre a influência da cobertura vegetal na proteção do solo contra a erosão pluvial comprovaram a importância das gramíneas e principalmente das florestas na proteção do solo, garantindo a interceptação das chuvas, infiltração e a diminuição do escoamento superficial. As áreas de plantio garantiram uma proteção inicial, formando uma "barreira" contra o escoamento superficial e produção de sedimentos, porém o problema se agrava após a colheita, em que o solo sofre compactação por ação das máquinas. É preciso cuidado no manejo de uso do solo com plantio, tentando equilibrar o uso às fragilidades do ambiente.

\section{REFERÊNCIAS}

BACCARO, C.A.D. Unidades Geomorfológicas do Triângulo Mineiro. Revista Sociedade \& Natureza. Uberlândia, 3 (5 e 6): 37-42, dezembro 1991.

BACCARO, C.A.D. Os estudos experimentais aplicados na avaliação dos processos geomorfológicos de escoamento pluvial em área de Cerrado. Revista Sociedade \& Natureza. Uberlândia: Edufu, ns. 9 e 10, p. 55-62, 1993.

BEZERRA, J.F.R.; GUERRA, A.J.T.; RODRIGUES, S.C. Monitoramento e avaliação de geotêxteis na recuperação de um solo degradado por erosão, Fazenda Experimental do Glória, Uberlândia - MG. 
In: VI Simpósio Nacional de Geomorfologia, 2006, Goiânia. Anais do VI Simpósio Nacional de Geomorfologia. 2006.

CARRIJO, B.R.; BACCARO, C.A.D. Análise sobre a erosão hídrica na área urbana de Uberlândia (MG). Caminhos de Geografia 1(2) p. 70-83. 2000.

ENVI. The Environment for Visualizing Images. Research Systems, Inc. Version 4.0. Copyright (C) 2003. Endereço eletrônico: http://www.ittvis.com/ envi/

EMPRESA BRASILEIRA DE PESQUISA AGROPECUÁRIA - EMBRAPA. Manual de métodos de análise de solo. $2^{\mathrm{a}}$ ed. Rio de Janeiro, CNPS - Ministério da Agricultura e do Abastecimento, 1997. 212p.

FALLEIRO, R.M.; SOUZA, C.M.; SILVA, C.S.W.; SEDIYAMA, C.S.; SILVA, A.A.; FAGUNDES, J.L. Influência dos sistemas de preparo nas propriedades químicas e físicas do solo. Revista Brasileira de Ciência do Solo. vol.27, $\mathrm{n}^{\circ}$ 6. Viçosa Nov./Dec., 2003.

GALETI, P.A. Conservação do Solo; Reflorestamento; Clima. 2. ed. Campinas, Instituto Campineiro de Ensino Agrícola, 1973.

GUERRA, A.J.T.; CUNHA, S.B. Geomorfologia: exercícios, técnicas e aplicações. Rio de Janeiro: Bertrand Brasil, 1996.

GUERRA, A.J.T.; SILVA, A.S.; \& BOTELHO, R.G.M. (Org). Erosão e Conservação dos Solos: conceitos, temas e aplicações. $2^{\mathrm{a}} \mathrm{Ed}$. Rio de Janeiro. Bertrand Brasil. 2005.

GUERRA, A.T.; GUERRA, A.J.T. Novo Dicionário Geológico e Geomorfológico. $5^{\mathrm{a}}$ ed. Rio de Janeiro: Bertrand Brasil, 2006.

IBGE. Instituto Brasileiro de Geografia e Estatística. Mapa de Solos do Brasil. 2001.
MICROSOFT. Microsoft Office Excel 2007. Microsoft Corporation, Copyright (C), 2008.

NISHIYAMA, L. Geologia do Município de Uberlândia e Áreas Adjacentes. Revista Sociedade e Natureza. Uberlândia, 1 (1): p. 9-16, junho 1989.

NUNES, M.C.M. Erosão hídrica em entressulcos de latossolos do Rio Grande do Sul. Tese de Doutorado em Ciência do Solo, Programa de PósGraduação em Ciência do Solo, Faculdade de Agronomia, Universidade Federal do Rio Grande do Sul, Porto Alegre, RS. (160 p.) Julho, 2006.

PINESE JÚNIOR, J.F.; GARBIN JUNIOR, E.; RODRIGUES, S.C. Análise do transporte de sedimentos com diferentes tipos de uso do solo em calhas de Gerlach (1967) na Fazenda Experimental do Glória, Uberlândia - MG. In: VI Simpósio Nacional de Geomorfologia, 2006, Goiânia. Anais do VI Simpósio Nacional de Geomorfologia. 2006. v. 01.p. 99.

PRIMAVESI, A. Manejo ecológico do solo: a agricultura em regiões tropicais. 6 . ed. São Paulo: Nobel, 1984.

RODRIGUES, S.C. Análise da fragilidade do relevo. Abordagem empírico-experimental. Revista Sociedade \& Natureza. Uberlândia, 12 (23): 167189, janeiro/junho. 2000.

SANTOS, P.G.; JULIATTI, F.C.; BUIATTI, A.L.; HAMAWAKI, O.T. Avaliação do desempenho agronômico de híbridos de milho em Uberlândia, MG. Pesquisa agropecuária brasileira, Brasília, v. 37, n. 5, p. 597-602, maio 2002.

SILVA, J.B. Avaliação da perda de solo por fluxo superficial utilizando parcelas experimentais: estudo de caso na bacia hidrográfica do córrego do Glória em Uberlândia - MG. Dissertação (mestrado) 2006 - Universidade Federal de Uberlândia, Programa de Pós-Graduação em Geografia. 2006. 147 p. 
SOUZA, L.H.F.. A Transformação Técnico-científica no Meio Rural brasileiro pós 1990: uma reflexão sobre os impactos herdados do processo de modernização agrícola. Revista Sociedade \& Natureza, Uberlândia, 17 (32): 47-60, jun. 2005.

TOWNSEND, C.R.; BEGON, M.; HARPER, J.L. Fundamentos em ecologia. 2. ed. Porto Alegre, Artmed, 2006. 592 p.

VOLK, L.B.S. Condições físicas da camada superficial do solo resultantes do seu manejo e indicadores de qualidade para redução da erosão hídrica e do escoamento superficial. Tese de Doutorado em Ciência do Solo, Programa de PósGraduação em Ciência do Solo, Faculdade de Agronomia, Universidade Federal do Rio Grande do Sul, Porto Alegre, RS. (149 p.) Setembro, 2006. 